\title{
Long-term outcomes of breast cancer in women aged 30 years or younger, based on family history, pathology and BRCA / BRRCA2/ TP53 status
}

\author{
DGR Evans ${ }^{*, 1,2}$, A Moran ${ }^{3}$, R Hartley ${ }^{3}$, J Dawson', B Bulman', F Knox ${ }^{4}$, A Howell ${ }^{2,5}$ and F Lalloo' \\ 'Manchester Academic Health Science Centre, Genetic Medicine, St Mary's Hospital, Central Manchester Hospitals Foundation Trust, Manchester M 3 \\ 9WL, UK: ${ }^{2}$ Genesis Prevention Centre, University Hospital of South Manchester and Wythenshawe Hospital NHS Foundation Trust, Manchester M23 \\ 9LT, UK; ${ }^{3}$ North Western Cancer Intelligence Senvice, Christie NHS Foundation Trust, Kinnaird Road, Manchester M20 9BX, UK; ${ }^{4}$ Department of \\ Pathology, University Hospital of South Manchester and Wythenshawe Hospital NHS Foundation Trust, Manchester M23 9LT, UK; ${ }^{5}$ CRUK Department \\ of Medical Oncology, The Christie NHS Trust, University of Manchester, Manchester M20 4BX, UK
}

BACKGROUND: There are relatively few articles addressing long-term follow-up in women with breast cancer at very young ages. METHODS: We have updated and extended our population-based analysis of breast cancer diagnosed at the age $\leqslant 30$ years in Northwest England to include an extra 15 patients with mutation testing in BRCA I, BRCA2 and TP53, with I I 5 of 288 consecutive cases being tested. Kaplan-Meier curves were generated to assess overall survival, contralateral breast cancer and other second primaries. RESULTS: Survival analysis of all 288 patients showed poor overall survival, although this improved from a I 5-year survival of only 46\% in those diagnosed between 1980 and 1989 to $58 \%$ in those diagnosed between 1990 and $1997(P=0.05)$. Contralateral breast cancer rates were at a steady rate of 0.6 per 1000, although the rates in mutation carriers were 2 per I000. Altogether, I6 BRCA I, 9 BRCA2 and 6 TP53 mutations have now been found among the 115 cases on whom DNA analysis has been performed. BRCAPRO accurately predicted the number of carriers for BRCAI and BRCA2 and was sensitive and specific at the 10 and $20 \%$ threshold, respectively. However, BRCAPRO did not seem to give any weight to DCIS, which accounted for two BRCAI carriers and three TP53 carriers and overpredicted mutations at the high end of the spectrum, with only 6 of II (54\%) with a >90\% probability having identifiable BRCA //2 mutations.

INTERPRETATION: Rates of new primaries are predicted to some extent by mutation status. BRCAPRO is useful at determining those patients aged $\leqslant 30$ years to be tested.

British Journal of Cancer (2010) I 02, I091-1098. doi:I0.1038/sj.bjc.6605606 www.bjcancer.com

Published online 16 March 2010

(c) 2010 Cancer Research UK

Keywords: BRCAI; BRCA2; TP53; familial breast cancer; family history

Mutations in BRCA1, BRCA2 and TP53 account for a proportion of early-onset and familial breast cancer. These mutations confer a lifetime breast cancer risk of 43-85\% (Varley et al, 1997; Ford et al, 1998). Several studies have investigated the frequency of BRCA1/2 and TP53 mutations in families with breast and/or ovarian cancer or Li-Fraumeni (LFS) or LFS-like (LFL) syndrome (Sidransky et al, 1992; Varley et al, 1997; Gayther et al, 1998; Peto et al, 1999; Loman et al, 2001). Among breast cancer cases unselected for family history (FH), the prevalence of BRCA1/2 mutations is dependent on the population studied and on the age at diagnosis of malignancy (Fitzgerald et al, 1996; Krainer et al, 1997; Peto et al, 1999; Loman et al, 2001). Although these papers have addressed the incidence of $B R C A 1 / 2$ in young women with

* Correspondence: Professor DGR Evans, Department of Clinical Genetics, St Mary's Hospital, Hathersage Road, Manchester MI 3 9WL, UK; E-mail: gareth.evans@cmft.nhs.uk

Received 23 December 2009; revised 16 February 2010; accepted 16 February 2010; published online 16 March 2010 breast cancer, data are still sparse in women diagnosed at very young ages ( $\leqslant 30$ years) and data are lacking for TP53.

Lalloo et al $(2003,2006)$ reported on the frequency and penetrance of BRCA1/2 and TP53 mutations in early-onset breast cancer in earlier papers. These papers showed a predominance of $B R C A 1 / 2$ mutations in familial aggregations of breast cancer, with penetrance estimates of breast cancer as high as $80-90 \%$ by 70 years of age. This paper presents a detailed analysis of survival, contralateral breast cancer and other tumour incidence in index cases aged $\leqslant 30$ years, both with and without $B R C A 1 / 2$ or TP53 mutations. It also presents results of including an extended series of BRCA1/2 and TP53 index cases diagnosed with breast cancer at $\leqslant 30$ years of age.

\section{METHODS}

\section{Patients}

The 288 original patients were ascertained from a populationbased series of consecutive breast cancers from the North Western 
Table I Diagnostic criteria for Li-Fraumeni syndrome and Li-Fraumeni-like syndrome

\begin{tabular}{ll}
$\begin{array}{l}\text { Li-Fraumeni syndrome } \\
\text { (Li et } \boldsymbol{a l}, \mathbf{1 9 8 8})\end{array}$ & $\begin{array}{l}\mathbf{L i}-\text { Fraumeni-like syndrome } \\
\text { (Birch et } \boldsymbol{a l}, \mathbf{1 9 9 4})\end{array}$ \\
\hline Proband $<45$ years with a sarcoma & $\begin{array}{l}\text { Proband }<45 \text { years with childhood } \\
\text { tumour, sarcoma, brain tumour or } \\
\text { adrenocortical tumour }\end{array}$ \\
$\begin{array}{l}\text { Plus first-degree relative }<45 \text { years } \\
\text { with any cancer }\end{array}$ & $\begin{array}{l}\text { in the same lineage with typical LFS } \\
\text { tumour at any age }\end{array}$ \\
$\begin{array}{l}\text { Plus additional first- or second-degree } \\
\text { relative in the same lineage aged }\end{array}$ & $\begin{array}{l}\text { Plus another first- or second-degree } \\
\text { relative in the same lineage with any } \\
\text { cancer }<60 \text { years }\end{array}$ \\
a sarcoma at any age &
\end{tabular}

Abbreviation: LFS $=$ Li-Fraumeni syndrome.

Cancer Intelligence Service (NWCIS) diagnosed with breast cancer at or under 30 years of age between 1 January 1980 and 31 December 1997. Diagnoses were confirmed using hospital records and pathology reports. Those patients who were proven to have a histological diagnosis other than breast carcinoma were excluded. Patients were approached through their consultant for permission to be interviewed and, after informed consent, to provide blood for DNA testing. A detailed three-generation pedigree was obtained along with copies of hospital notes, where available. Family histories of malignancy were confirmed through the cancer registry, hospital notes or death certificates.

Patients were classified as familial, LFS, LFL or non-familial groups on the basis of $\mathrm{FH}$ at initial diagnosis. Familial patients were defined as those with a FH of breast cancer $<65$ years of age or ovarian cancer at any age in first- or second-degree relatives at the time of the index cases' primary breast cancer diagnosis. Both LFS and LFL were defined as in Table 1.

A further series of 84 patients diagnosed with breast cancer at or under 30 years of age who had tested positive for mutations in $B R C A 1 / 2$ or TP53 were included for some analyses of contralateral and other tumour risks to enrich the inherited subtypes. Of these patients, 24 were diagnosed in the northwest after 31 December 1997.

Kaplan-Meier (KM) survival curves from diagnosis of breast cancer were derived from the original series alone, with ductal carcinoma in situ (DCIS) included and excluded. A comparison between cases diagnosed before and after 1990 was also undertaken. Kaplan-Meier curves were derived for the occurrence of contralateral breast cancer after the initial diagnosis and for other cancer diagnoses following initial breast cancer diagnosis with the inclusion of mutation carriers from the additional data set. Kaplan-Meier curves for contralateral breast cancer from diagnosis were derived using the enriched data set with a confirmed FH or mutation: comparisons were made between no $\mathrm{FH}$ (sporadic): BRCA1; BRCA2; TP53; and FH but no mutation.

\section{Mutation analysis}

All samples were screened for mutations in BRCA1, BRCA2 and TP53 as described previously (Lalloo et al, 2003). Since then, further mutation screening of $B R C A 1$ and $B R C A 2$ has been undertaken using direct sequencing and multiple ligation-dependent probe amplification, which is a dosage test to detect large single or multiple exon deletions or duplications. An additional 15 samples have become available for mutation testing from the original $\leqslant 30$ series.

\section{Pathology}

Pathology was taken from the original pathology report and NWCIS entry. All available tumours from patients who had donated blood samples for DNA analysis were reviewed by a single pathologist (FK). Oestrogen receptor (ER) (6F11 Novocastra, Bannockburn, IL, USA), PR (PGR312 Novocastra) and HER2 (c-erbB2 CB11 Novocastra) immunohistochemistry was performed in cases in which tissue was available. Both ER and PR were scored using the Allred (Quick) score based on the assessment of both proportion and intensity of staining. Her-2 was scored according to standard protocol (Ellis et al, 2004). The ER status was considered negative if the Quick score was $0 / 8$ or if $<5 \%$ cells were positive by immunohistochemistry. Her-2 was regarded as positive if the tumour showed gene amplification by fluorescent in situ hybridisation (FISH) or, in the absence of FISH, if the immunohistochemical score was $3+$ (scale of $0-3$ ).

\section{Model prediction}

Carrier probabilities of BRCA1 and BRCA2 using BRCAPRO and Myriad were calculated using the CancerGene software package (CaGene version 4.3.2) from the University of Texas Southwestern Medical Center (Houston, TX, USA). Additional information about CancerGene is available at http://www.utsouthwestern.edu. The Manchester scoring system was used for comparison (Evans et al, 2004). Carrier status was calculated at last follow-up or death of the affected woman to take into account bilateral disease and newer FH. Assessments were made for a 10 and $20 \%$ detection rate for each gene and BRCA1/2 combined.

\section{Statistical analysis}

Assessment of KM curves was undertaken by $\chi^{2}$ test by comparing each grouping separately with all others for BRCA1, BRCA2, TP53, familial mutation negative and sporadic mutation negative. Ninety-five percent confidence intervals (CIs) were derived for survival and contralateral tumour incidence.

\section{RESULTS}

A total of 276 women were registered on the NWCIS with confirmed early-onset primary breast carcinoma diagnosed between 1 January 1980 and 31 December 1997 in the strict regional boundaries. At original ascertainment between 1993 and December 1997, 116 (42\%) women were dead and 160 (58\%) were alive. As of December 2008, $144(52 \%)$ women were dead and $132(48 \%)$ were alive. The age of diagnosis and grade of tumour did not significantly differ between the living and dead cases. The mean age at diagnosis was 28 years and 3 months (range 18 years 5 months to 30 years 11 months). Consultant permission to approach the patient was refused for 26 living patients (4 subsequently came forward unprompted). Of the remaining 135 cases, 102 consented to participate, 32 refused and 1 could not be traced. Blood samples were available from a further five deceased patients, and were tested after family consent. Further blood samples were obtained from an additional 8 of 12 women affected at the appropriate age and study period on the NWCIS, but outside the strict regional boundaries. As such, genetic status could be established for 115 women from the NWCIS who developed breast cancer at $\leqslant 30$ years of age ( 15 more than our previous report).

In all, 46 patients (42\%) had a significant $\mathrm{FH}$, which was consistent with LFS or LFL in 6 cases. A further five women had a $\mathrm{FH}$ of breast cancer, which was not consistent with the original study (breast cancer in third-degree relatives or $>65$ years of age). The remaining 64 cases had no known FH of breast or ovarian cancer at the time of diagnosis and were classified as non-familial.

\section{Molecular analysis}

Overall, pathogenic mutations in BRCA1, BRCA2 and TP53 were identified in 31 women: 26 of 53 (49\%) familial and 5 of $62(8 \%)$ 
non-familial cases (Tables 2-4). Three patients with BRCA1/2 mutations were sporadic at the time of diagnosis and one patient had only a paternal grandmother with breast cancer aged 65 years. In all four cases, the history changed over follow-up. Two women developed bilateral disease (cases 9 and 16, Table 5) and in the

Table 2 Histology and vital status on 276 incident breast cancer patients $\leqslant 30$ years and 12 additional cases from the NWCIS

\begin{tabular}{|c|c|c|c|}
\hline & Total & Alive (\%) & $\begin{array}{c}\text { Deaths from breast } \\
\text { or other cancer }\end{array}$ \\
\hline IDC grade 3 ER negative & 40 & $30(75 \%)$ & 10 \\
\hline IDC grade 3 ER positive & 19 & $15(79 \%)$ & 4 \\
\hline $\begin{array}{l}\text { IDC grade } 3 \text { no receptor } \\
\text { status }\end{array}$ & 60 & $25(42 \%)$ & 35 \\
\hline All grade 3 & 119 & 70 (59\%) & 49 \\
\hline IDC grade 2 & 37 & $14(38 \%)$ & 23 \\
\hline IDC grade I & 9 & $4(45 \%)$ & 5 \\
\hline DCIS & 18 & $13(72 \%)$ & 5 \\
\hline $\begin{array}{l}\text { IDC no grade on pathology } \\
\text { report }\end{array}$ & 90 & $35(39 \%)$ & 53 \\
\hline Lobular invasive & 8 & $4(50 \%)$ & 4 \\
\hline Scirrhous & 3 & I (33\%) & 2 \\
\hline LCIS & 2 & $2(100 \%)$ & 0 \\
\hline Spheroidal & 2 & $0(0 \%)$ & 2 \\
\hline Mucinous & I & $0(0 \%)$ & । \\
\hline SCC nipple & 1 & | (100\%) & 0 \\
\hline Total & 288 & 144 & 144 \\
\hline
\end{tabular}

Abbreviations: $\mathrm{DCIS}=$ ductal carcinoma in situ; $\mathrm{ER}=$ oestrogen receptor; $\mathrm{IDC}=$ invasive Ductal Carcinoma; LCIS = Lobular Carcinoma in situ; NWCIS = North Western Cancer Intelligence Service; SCC $=$ Squamous Cell Carcinoma

Table 3 Pathology characteristics of I I5 patients with DNA testing

\begin{tabular}{lccccc}
\hline & Total & BRCA & BRCA2 & TP53 & Any mutation \\
\hline IDC grade 3 ER negative & 35 & 10 & 0 & 0 & $10 / 35$ \\
IDC grade 3 ER positive & 16 & 1 & 4 & 0 & $5 / 16$ \\
IDC grade 3 no receptor & 16 & 2 & 2 & 0 & $4 / 16$ \\
status & & & & & \\
IDC grade 2 & 15 & 0 & 2 & 0 & $2 / 15$ \\
IDC grade I & 4 & 0 & 0 & 0 & $0 / 4$ \\
DCIS & 1 & 2 & 0 & 3 & $5 / 11$ \\
IDC no grade & 10 & 0 & 0 & 1 & $1 / 10$ \\
Lobular invasive & 4 & 1 & 0 & 0 & $1 / 4$ \\
LCIS & 2 & 0 & 0 & 0 & $0 / 2$ \\
Spheroidal & 2 & 0 & 1 & 1 & $2 / 2$ \\
Mucinous & 1 & 0 & 0 & 0 & $0 / 1$ \\
SCC nipple & 1 & 0 & 0 & 0 & $0 / 1$ \\
Total & 115 & $16(14 \%)$ & $9(8 \%)$ & $5(5 \%)$ & $29 / 115(25 \%)$ \\
\hline
\end{tabular}

Abbreviations: $D C I S=$ ductal carcinoma in situ; $E R=$ oestrogen receptor; IDC = invasive Ductal Carcinoma; LCIS = Lobular Carcinoma in situ; SCC = Squamous Cell Carcinoma. other two, a FH of ovarian cancer and breast cancer developed after their own diagnosis.

Pathogenic BRCA1 mutations were identified in 16 women $(14 \%)$ diagnosed with breast cancer at $\leqslant 30$ years of age. BRCA2 mutations were detected in nine women (8\%). Pathogenic TP53 mutations were found in 5 patients (5\%) including 3 of $6(50 \%)$ of the LFS/LFL subgroup. The updated analysis demonstrated an additional TP53 mutation: $659 \mathrm{~A}>\mathrm{G}$ in a family fulfilling LFS criteria, four further BRCA 1 mutations $(2682 \mathrm{C}>\mathrm{T}$, del exons $1-17$, del exons 5-17, 1953DupG) in four familial breast cancers and 1 BRCA2 mutation $(1058 \mathrm{C}>\mathrm{A})$ out of the 15 additional samples obtained since our last report (Lalloo et al, 2006). The pathology characteristics based on mutation status are presented in Table 3. Table 4 shows a more detailed breakdown of grade 3 tumours. Only in grade 3 triple-negative breast cancer does the rate of $B R C A 1$ mutation among sporadic cases increase above $10 \%$ ( 2 of 16$)$. However, the overall detection rate in all triplenegative grade 3 cases including those with a $\mathrm{FH}$ was 10 out of $27(37 \%)$.

An additional 30 patients with $B R C A 1$ mutations diagnosed at $\leqslant 30$ years of age after 31 December 1979 and 19 with BRCA2 mutations with the same criteria were identified from our clinic mutation database. In addition, six TP53 carriers diagnosed at $\leqslant 30$ years of age were found. In all, 13 of the total 84 mutation carriers (46 BRCA1, 27 $B R C A 2,11$ TP53) have had risk-reducing contralateral mastectomy (RRM) representing $20 \%$ of the total. We are not aware of any RRMs being performed in the remaining patients.

\section{Survival}

Of the 288 cases in the population-based series, 18 had carcinoma in situ as their initial diagnosis. Of these cases, two had comedo DCIS and were shown to have a TP53 mutation. They subsequently died from a primary glioma and retroperitoneal sarcoma, respectively. Two patients died from subsequent ipsilateral invasive breast cancer and one from non-cancer-related event. Survival analysis from diagnosis in the whole data set is presented in Figure 1. Survival decreases below $50 \%$ at the 15-year point. However, this masks a difference between those cases diagnosed before and after 1990. Rates of 5-, 10- and 15 -year survival were $69 \%$ (95\% CI: 65-73\%), 58\% (95\% CI: $54-62 \%)$ and $57 \%$ (95\% CI: $53-61 \%)$, respectively, in 133 women diagnosed after 1990 compared with 61\% (95\% CI: 57-65\%), 49\% (95\% CI: $45-53 \%)$ and 46\% (95\% CI: $42-50 \%)$, respectively, in 155 women diagnosed before 1990 (hazard ratio 1.38 $P=0.05)$

\section{Contralateral breast cancer incidence}

Contralateral breast cancer incidence is shown in Figure 2A and B. The incidence of contralateral breast cancer up to 20 years of follow-up is $0.6 \%$ per year. (Figure $2 \mathrm{~A}$ ). In all, 19 contralateral breast cancers occurred in follow-up (Table 5): 1 in a TP53 carrier,

Table 4 Frequency of constitutional BRCAI and BRCA2 mutation in grade 3 IDC with oestrogen receptor status and triple negative status in a population based study of breast cancer patients $\leqslant 30$ years

\begin{tabular}{|c|c|c|c|c|c|c|}
\hline & $\begin{array}{l}\text { All IDC grade } \\
3 \text { ER negative }\end{array}$ & $\begin{array}{l}\text { All IDC grade } \\
3 \text { triple negative }\end{array}$ & $\begin{array}{l}\text { Grade } 3 \text { IDC no hormone } \\
\text { receptor status available }\end{array}$ & $\begin{array}{l}\text { Grade } 3 \\
\text { ER positive }\end{array}$ & $\begin{array}{c}\text { All } \\
\text { Grade } 3\end{array}$ & $\begin{array}{c}\text { All breast } \\
\text { cancer cases }\end{array}$ \\
\hline BRCA I: all cases & 10/35 (29\%) & 10/27 (37\%) & $2 / 16(14 \%)$ & $1 / 16(6 \%)$ & $13 / 67(19.5 \%)$ & $16 / 115(14 \%)$ \\
\hline BRCA2: all cases & $0 / 35$ & $0 / 27$ & $2 / 16(12 \%)$ & $4 / 16(25 \%)$ & $6 / 67(9 \%)$ & $9 / 115(8 \%)$ \\
\hline Sporadic & $0 / 22$ & $0 / 16$ & $1 / 7(14 \%)$ & $0 / 11$ & $1 / 40(2.5 \%)$ & $1 / 62(1.5 \%)$ \\
\hline Familial & $0 / 13$ & $0 / 11$ & $1 / 9(11 \%)$ & $4 / 5(80 \%)$ & $5 / 27(18 \%)$ & $8 / 53(15 \%)$ \\
\hline
\end{tabular}

Abbreviations: ER = oestrogen receptor; FISH = fluorescent in situ hybridisation. In all, 37 of 67 (55\%) grade 3 tumours had HER2 status assessed on pathology review. Eight (22\%) were HER2 positive on FISH analysis. 
Table 5 Performance of BRCAPRO and Myriad models in predicting BRCAI/2 mutation status

\begin{tabular}{|c|c|c|c|c|c|c|c|c|}
\hline & Number & $\begin{array}{c}\text { BRCAPRO } \\
\text { BRCAI }\end{array}$ & $\begin{array}{l}\text { BRCAPRO } \\
\text { BRCA2 }\end{array}$ & $\begin{array}{l}\text { BRCAPRO } \\
\text { combined }\end{array}$ & Myriad & $\begin{array}{l}\text { BRCAI } \\
\text { actual }\end{array}$ & $\begin{array}{l}\text { BRCA2 } \\
\text { actual }\end{array}$ & $\begin{array}{c}\text { Combined } \\
B R C A I+B R C A 2\end{array}$ \\
\hline Sporadic breast cancer & 64 & 3.47 & 2.14 & 7.6 & 4.2 & 2 & 1 & 3 \\
\hline Sporadic breast cancer unilateral & 54 & I.l & I & 2.1 & 3.6 & 1 & 1 & 2 \\
\hline Bilateral breast cancer & 17 & 7.6 & 3.0 & 10.6 & 2.2 & 4 & 1 & 5 \\
\hline Bilateral sporadic & 8 & 2.35 & 1.15 & 3.5 & 0.5 & 1 & 0 & 1 \\
\hline Bilateral family history positive & 9 & 5.3 & 1.8 & 7.1 & 1.7 & 3 & 1 & 4 \\
\hline Familial unilateral & 43 & 10.4 & 4.4 & 14.8 & 6.4 & || & 7 & 18 \\
\hline DCIS & 11 & 0.60 & 0.35 & 0.95 & 0.4 & 2 & 0 & 2 \\
\hline Total & $1 / 5$ & 19.2 & 8.4 & 27.6 & 12.4 & 16 & 9 & 25 \\
\hline
\end{tabular}

Abbreviation: $\mathrm{DCIS}=$ ductal carcinoma in situ.

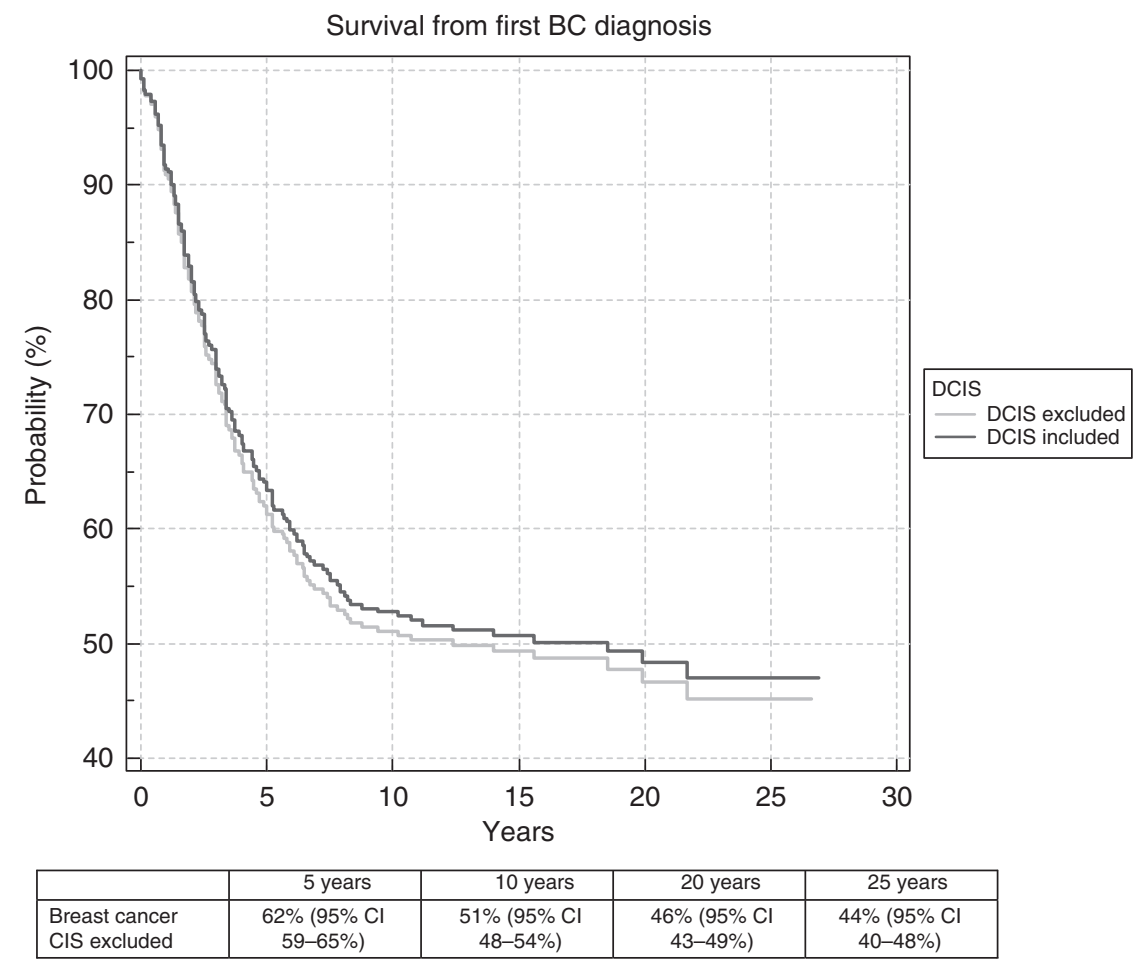

Figure I Survival from breast cancer diagnosis in 288 breast cancer cases aged $\leqslant 30$ years and diagnosed between 1980 and 1997.

4 in BRCA1 carriers and 1 in BRCA2. In the enriched mutation carrier data set, there is a $2 \%$ annual risk of contralateral breast cancer up until 15 years, after which the number of patients is too small for any stable estimate (Figure $2 \mathrm{~B}$ ).

\section{Other cancer incidence}

The incidence of non-breast primary cancer was $4.2 \%$ at 25 years (Supplementary Table). Surprisingly, no ovarian cancer has so far occurred even among $B R C A 1 / 2$ carriers, given the fact that the age of these women now without oophorectomy is $38-55$ years. Indeed, in 620.5 years of follow-up in the enhanced data set of 72 women with $B R C A 1 / 2$ mutations (censored at date of oophorectomy in 13 women), no ovarian cancers have occurred. Of 59 women with intact ovaries, 25 are now $>40$ years of age.

\section{Model performances}

Performance of the BRCAPRO model and myriad tables can be seen in Tables 5 and 6 . BRCAPRO performed well, especially in unilateral cases, although it seemed to overestimate in bilateral cases $(P=0.05)$. In isolated sporadic unilateral cases, the only patient exceeding the $10 \%$ threshold $(25.8 \%)$ with BRCAPRO was a Jewish woman who did not have a mutation. In 11 families with a predicted $B R C A 1 / 2$ mutation status $>90 \%$ (10.47 predicted), only 6 BRCA1/2 mutations were found (1 in BRCA2). Two of the TP53 carriers had a predicted $B R C A 1 / 2$ score of $>90 \%(95.3,94.3 \%)$. The prediction of DCIS cases is also presented in Table 5. Although both the BRCA1 carriers with DCIS reached the $10 \%$ combined threshold, it is clear that this was because of the very strong FH. Indeed, there seems to be no weighting for DCIS, as sporadic cases had a $0 \%$ rating for $B R C A 1$ and even those with a $\mathrm{FH}$ were no more likely in BRCAPRO to be a BRCA1 carrier than an unaffected sibling.

The myriad model did not perform well with poor sensitivity, especially at the $20 \%$ level. The Manchester score was partly developed using initial data from this series before the extended follow-up and addition of 15 women. Using the updated pathology-adjusted Manchester score (Evans et al, 2009), sensitivity at the $20 \%$ level improved from 80 to $88 \%$ (Table 6). 
A

Risk of contralateral breast cancer from original diagnosis

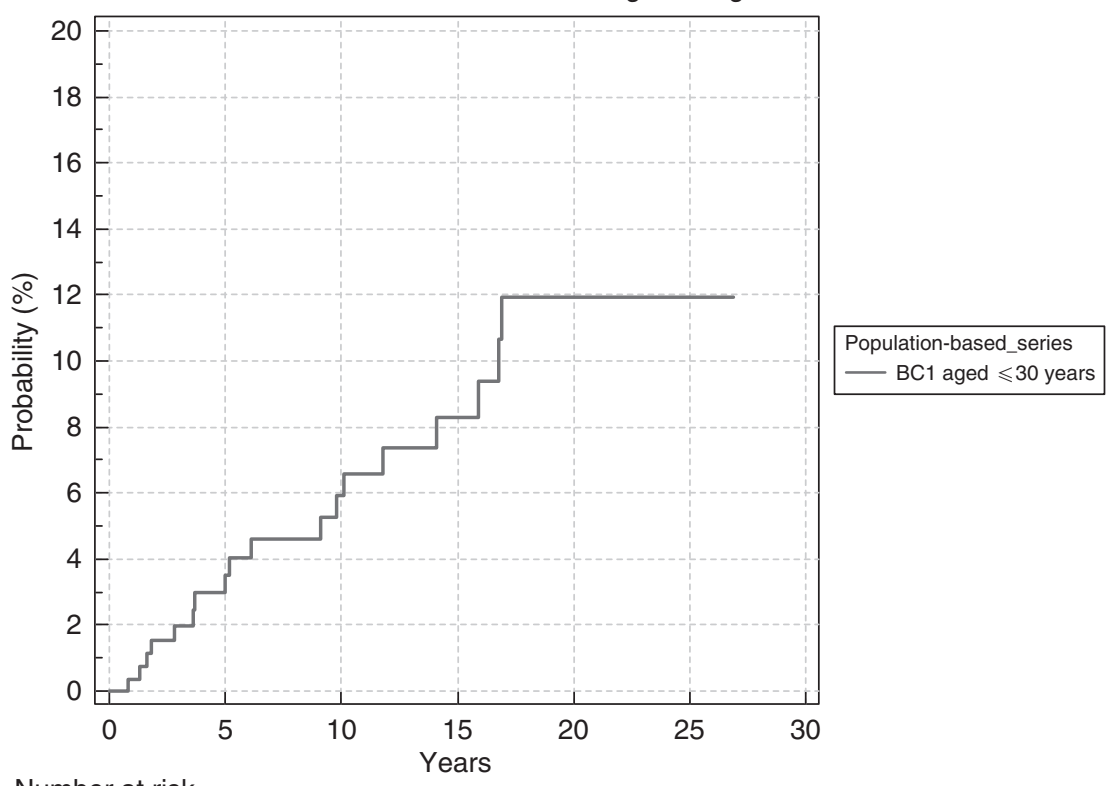

Number at risk

$\begin{array}{lllllll}291 & 179 & 140 & 90 & 46 & 11 & 1\end{array}$

B Risk of BC2 where BC1 diagnosed at age $<31$

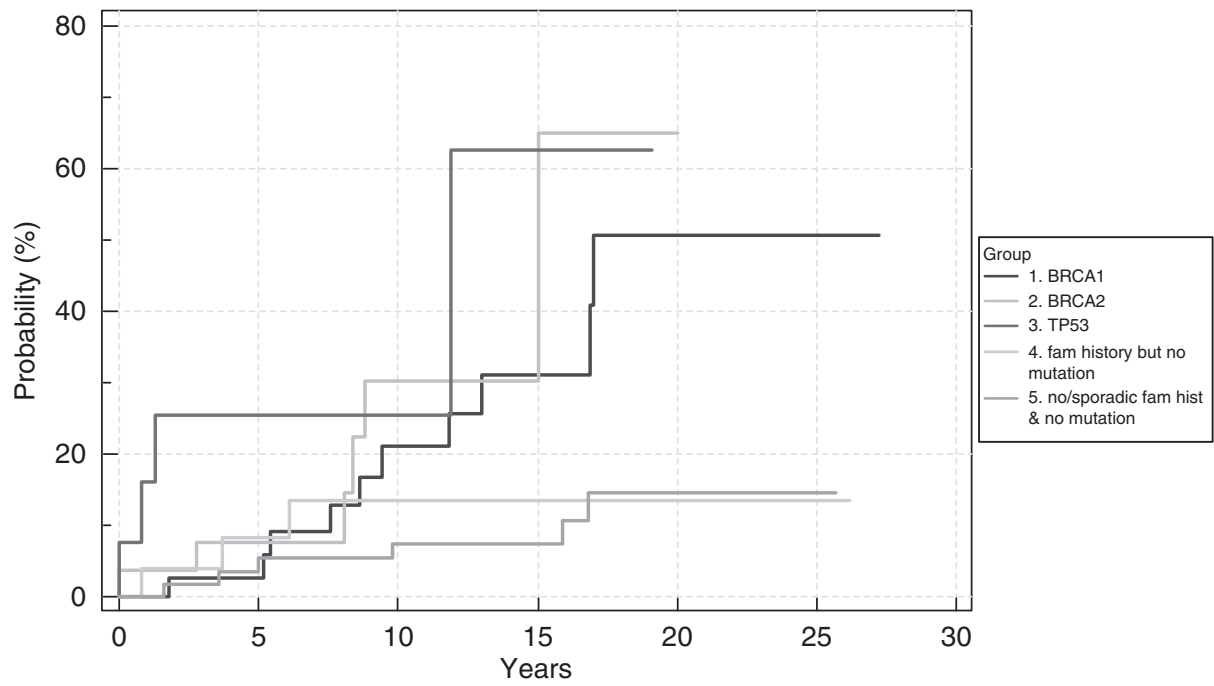

Number at risk

Group: 1. BRCA1

$\begin{array}{lllllll}44 & 30 & 18 & 8 & 4 & 2 & 1\end{array}$

Group: 2. BRCA2

$\begin{array}{lllllll}26 & 21 & 7 & 1 & 0 & 0 & 0\end{array}$

Group: 3. TP53

$\begin{array}{lllllll}11 & 5 & 3 & 1 & 0 & 0 & 0\end{array}$

Group: 4. fam history but no mutation

$\begin{array}{lllllll}25 & 20 & 17 & 11 & 6 & 1 & 0\end{array}$

Group: 5. no/sporadic fam hist \& no mutation
60
52
45
32
11
1
0

Figure 2 (A) Contralateral breast cancer cumulative incidence in all incident breast cancer cases aged $\leqslant 30$ years. (B) Contralateral breast cancer cumulative incidence in BRCAI, BRCA2 and TP53 breast cancer cases at $\leqslant 30$ years of age and in mutation-negative groups.

\section{DISCUSSION}

This study has updated the previous comprehensive analysis of FH and mutation analysis for all three high-risk breast cancer genes in women diagnosed with breast cancer aged $\leqslant 30$ years to include an additional 15 patients with 5 new pathogenic mutations. The analysis of contralateral disease, non-breast primaries and survival has been enriched with additional patients diagnosed at 
Table 6 Sensitivity and specificity of BRCAPRO and Myriad tables at the 10 and $20 \%$ level for BRCA I, BRCA2 and both genes combined

\begin{tabular}{|c|c|c|c|c|}
\hline Model/scoring system & Sensitivity & Specificity & Positive predictive value & Negative predictive value \\
\hline BRCAPRO combined $10 \%$ & $23 / 25(92 \%)$ & $65 / 90(72 \%)$ & $23 / 48(48 \%)$ & $65 / 67(97 \%)$ \\
\hline BRCAPRO combined $20 \%$ & $20 / 25(80 \%)$ & $73 / 90(81 \%)$ & $20 / 37(54 \%)$ & $73 / 78(94 \%)$ \\
\hline BRCAPRO BRCAI IO\% & $14 / 16(87.5 \%)$ & $72 / 99(72 \%)$ & $|4 / 4|(34 \%)$ & $72 / 74(97 \%)$ \\
\hline BRCAPRO BRCA2 I0\% & $4 / 9(44 \%)$ & $78 / 106(74 \%)$ & $4 / 32(12.5 \%)$ & $78 / 83(94 \%)$ \\
\hline Myriad $10 \%$ & $18 / 25(72 \%)$ & $76 / 90(84 \%)$ & $18 / 32(56 \%)$ & $76 / 83(92 \%)$ \\
\hline Myriad 20\% & $8 / 25(32 \%)$ & $86 / 90(96 \%)$ & $8 / 12(75 \%)$ & $86 / 103(83 \%)$ \\
\hline MANCHESTER combined $10 \%$ & $25 / 25(100 \%)$ & $57 / 90(63 \%)$ & $25 / 58(43 \%)$ & $57 / 57(100 \%)$ \\
\hline MANCHESTER combined 20\% & $20 / 25(80 \%)$ & $77 / 90(86 \%)$ & $20 / 33(60 \%)$ & $77 / 82(94 \%)$ \\
\hline MANCHESTER BRCAI I0\% & $15 / 16(94 \%)$ & $73 / 99(73 \%)$ & $|5 / 4|(37 \%)$ & $73 / 74(99 \%)$ \\
\hline MANCHESTER BRCA2 $10 \%$ & $6 / 9(67 \%)$ & $78 / 106(74 \%)$ & $6 / 34(18 \%)$ & $78 / 81(96 \%)$ \\
\hline
\end{tabular}

the age of $\leqslant 30$ years from our mutation database. We have previously published the prevalence of both BRCA1/2 and TP53 mutations in this cohort (Lalloo et al, 2003), demonstrating a higher prevalence of TP53 mutations than previously expected. The mutation detection rate in familial breast cancer in these three genes is $\sim 50 \%$ (26 of 53 ), demonstrating the importance of accurately documenting a $\mathrm{FH}$ when estimating the likelihood of a mutation carrier. Few mutations were found in those women without a FH. These data would therefore not support the testing of $B R C A 1 / 2$ in patients below the age of 31 years without a $\mathrm{FH}$ of breast cancer. In particular, even in sporadic cases with grade 3 cancers, the detection rate was only 5\%. Among grade 3 triple-negative sporadic cases, the rate of mutation detection was only $12.5 \%$ ( 2 of 16). Lakhani et al (2005) reported data on the likelihood of breast cancer being caused by a BRCA1 mutation by pathological grade and ER status at various ages in women not selected by FH. These data were also from an unselected series. Women aged between 20 and 29 years with grade 3 ER-negative breast cancers had a $35 \%$ chance of a BRCA1 mutation, with a similarly high risk for women aged 30-34 years at $26.5 \%$. Only after the age of 34 years did the risks fall below $10 \%$ (Lakhani et al, 2005). However, these figures include all women, even those with a FH. Unfortunately, it seems that some clinicians have misinterpreted these data and called for all women $<35$ years of age with pathological grade 3 and ER-negative breast cancer to be tested, or has offered testing on the basis of a $10-20 \%$ testing threshold. Our population-based data confirm a similar 29\% risk for young women (age $<31$ years). This suggests that only triple-negative, pathological grade 3 breast cancers in women $<31$ years of age qualify for testing, irrespective of $\mathrm{FH}$, on the basis of guidelines using a 10\% threshold in outbred populations. Clearly, the CIs are wide on these numbers, and further studies to assess the rates of mutations in sporadic triple-negative patients will help inform models and scoring systems further. For instance, a recent North American study demonstrated mutations in $9 \%$ of triple-negative breast cancer patients aged $<40$ years without, or with minimal, $\mathrm{FH}$ of breast or ovarian cancer (Young et al, 2009). However, this study did not describe the FH. Nevertheless, use of pathology in our pathology-adjusted Manchester score (Evans et al, 2009) improved sensitivity at the $20 \%$ threshold by detecting two further mutations at the cost of testing only three further samples.

The data in the current analysis demonstrate the improvement in survival in breast cancer, which is seen in many countries. In the United Kingdom, a more formal approach for breast surgery including axillary node dissection and treatment of all ipsilateral breast tissue (radiotherapy in those undergoing local excision) was highlighted in 1990 (Fentiman and Mansel, 1991). This more formalised treatment schedule may in part explain the significant improvement in survival from diagnosis with time. Nevertheless, overall survival is still poor in this group of young women.
This is likely to be related to a more aggressive phenotype with less hormonally sensitive cancers (Figueiredo et al, 2007; Anders et al, 2008). The poor prognosis seems to particularly apply to breast cancer patients at age $<35$ years and is consistent between studies in the United Kingdom, North America and Asia (Nixon et al, 1994; Jmor et al, 2002; Han and Kang, 2010).

The diagnosis of a second primary tumour should prompt the clinician to consider a TP53 mutation. One patient with a renal carcinoma and a de novo TP53 mutation went on to develop a sarcoma behind the remaining kidney that was subjected to regular screening radiation from intravenous urograms. An oesophageal cancer also occurred in a BRCA2 carrier. However, surprisingly, no ovarian cancers occurred in $B R C A 1 / 2$ carriers, even though 21 women have lived beyond 40 years of age without an oophorectomy. Population studies have indicated that the subsequent ovarian cancer risk is higher if an individual is diagnosed with breast cancer at a young age, particularly if there is a FH of ovarian cancer (Bergfeldt et al, 2002). This is most likely to suggest a high probability of a $B R C A 1 / 2$ mutation rather than another mechanism increasing ovarian cancer risk. The data from our study do not suggest a higher ovarian cancer risk in women with known mutations with early-onset breast cancer, compared with mutation carriers with later-onset disease.

This study assessed the performance of mutation prediction models in this population-based data set. We chose to assess the models at last follow-up to determine how the models dealt with new contralateral disease. Direct comparisons with the Manchester scoring system are inappropriate, as this system was partly developed from the original data set at the time of diagnosis. Another model, BOADICEA, also used this data set in development (Antoniou et al, 2008). BRCAPRO (Parmigiani et al, 1998) performs well, especially in unilateral cases. As no non-Jewish sporadic case (even the adopted individuals) reached the $10 \%$ combined threshold even at the time of diagnosis, this supports the hypothesis that, in Western populations, the rates of $B R C A 1 / 2$ mutations even in early-onset breast cancer cases without a $\mathrm{FH}$ are low. An adopted sporadic case would need to be diagnosed at the age of $\leqslant 24$ years to breach the threshold using BRCAPRO. Nevertheless, BRCAPRO does seem to overestimate the BRCA1/2 probabilities in bilateral cases. It is also interesting to note the handling of DCIS. Although both BRCA1 carriers with DCIS were identified using the $10 \%$ combined threshold, they were as likely to be a carrier as an unaffected sibling. It seems that no weight is given to DCIS to increase either the $B R C A 1$ or $B R C A 2$ probability of either the individual or the family in BRCAPRO. Ductal carcinoma in situ at the age of $\leqslant 30$ years is clearly an important diagnosis, as $45 \%$ of the 11 cases had a pathogenic mutation, with DCIS being a particular marker for a TP53 mutation. The myriad tables (Frank et al, 2002) do not have a specific readout for bilateral disease and therefore should probably not be used to 
assess families with this disease. No patient using the Myriad tables had a score above $39.2 \%$ for likelihood of a mutation. There also seems to be a degree of overestimation at the top end of the BRCAPRO model. The model does not allow for sensitivity of mutation techniques, as scores of up to $100 \%$ are possible. The model also does not allow for the possibility of other highpenetrance genes, as two of the TP53 carriers had scores above $94 \%$, yet their FHs were consistent with LFS. We have estimated that a combined score of $40+$ using the Manchester score suggests a very high probability of a $B R C A 1 / 2$ mutation (Evans et al, 2009). Using this threshold, six of seven samples had a detectable mutation.

The strengths of this study are that it is population based and has obtained DNA samples on the great majority of living cases. Overall death rates and second primary rates are secure because of the cancer intelligence service.

This study does have some limitations. The pathology reports on patients diagnosed before 1990 had little information with regard to grade and do not have information regarding hormone receptor status. It was not possible to determine reliable survival data on the basis of tumour grade as a result of this deficiency. However, in the group that submitted a blood sample, a detailed pathological review was possible in most cases.

\section{Summary}

This analysis has shown an improvement in survival for women with very early-onset breast cancer in more recent years. There are high rates of BRCA1, BRCA2 and TP53 mutations in women aged $\leqslant 30$ years with a FH. Among sporadic patients, mutations are generally in those with grade 3 triple-negative tumours. Rates of further primary tumours other than contralateral breast cancer are not high, except in TP53 carriers, and very young-onset BRCA1/2 carriers do not seem to be at enhanced risk of ovarian cancer compared with other $B R C A 1 / 2$ carriers. Contralateral breast cancer rates seem stable at $\sim 0.6 \%$ annually in all women and at $2-3 \%$ in mutation carriers.

\section{ACKNOWLEDGEMENTS}

DGRE and FL are supported by the NIHR Biomedical Research Centre, Manchester. Additional grant support was provided by The Genesis Appeal.

Supplementary Information accompanies the paper on British Journal of Cancer website (http://www.nature.com/bjc)

\section{REFERENCES}

Anders CK, Hsu DS, Broadwater G, Acharya CR, Foekens JA, Zhang Y, Wang Y, Marcom PK, Marks JR, Febbo PG, Nevins JR, Potti A, Blackwell KL (2008) Young age at diagnosis correlates with worse prognosis and defines a subset of breast cancers with shared patterns of gene expression. J Clin Oncol 26(20): 3324-3330

Antoniou AC, Cunningham AP, Peto J, Evans DG, Lalloo F, Narod SA, Risch HA, Eyfjord JE, Hopper JL, Southey MC, Olsson H, Johannsson O, Borg A, Passini B, Radice P, Manoukian S, Eccles DM, Tang N, Olah E, Anton-Culver H, Warner E, Lubinski J, Gronwald J, Gorski B, Tryggvadottir L, Syrjakoski K, Kallioniemi OP, Eerola H, Nevanlinna H, Pharoah PD, Easton DF (2008) The BOADICEA model of genetic susceptibility to breast and ovarian cancers: updates and extensions. $\mathrm{Br} J$ Cancer 45(7): 425-431

Bergfeldt K, Rydh B, Granath F, Grönberg H, Thalib L, Adami HO, Hall P (2002) Risk of ovarian cancer in breast-cancer patients with a family history of breast or ovarian cancer: a population-based cohort study. Lancet 360(9337): 891-894

Birch JM, Hartley AL, Tricker KJ, Prosser J, Condie A, Kelsey AM, Harris M, Morris-Jones PH, Crowther D, Craft AW, Eden OB, Evans DGR, Thompson E, Mann J, Martin J, Mitchell ELD, Santibanez-Koref MF (1994) Prevalence and diversity of constitutional mutations in the p53 gene among $21 \mathrm{Li}$-Fraumeni families. Cancer Res 54: 1298-1304

Ellis IO, Bartlett J, Dowsett M, Humphreys S, Jasani B, Miller K, Pinder SE, Rhodes A, Walker R (2004) Updated recommendations for Her-2 testing in the UK. J Clin Pathol 57: 233-237

Evans DG, Lalloo F, Cramer A, Jones E, Knox F, Amir E, Howell A (2009) Addition of pathology and biomarker information significantly improves the performance of the Manchester scoring system for BRCA1 and BRCA2 testing. J Med Genet 46(12): 811-817

Evans DGR, Eccles DM, Rahman N, Young K, Bulman M, Amir E, Shenton A, Howell A, Lalloo F (2004) A new scoring system for the chances of identifying a BRCA1/2 mutation, outperforms existing models including BRCAPRO. J Med Genet 41(6): 474-480

Fentiman IS, Mansel RE (1991) The axilla: not a no-go zone. Lancet 337(8735): $221-223$

Figueiredo JC, Ennis M, Knight JA, McLaughlin JR, Hood N, O’Malley F, Andrulis IL, Goodwin PJ (2007) Influence of young age at diagnosis and family history of breast or ovarian cancer on breast cancer outcomes in a population-based cohort study. Breast Cancer Res Treat 105(1): 69-80

Fitzgerald MG, Macdonald DJ, Krainer M, Hoover I, O’Neil E, Unsal H, Silva-Arrietto S, Finklestein DM, Beer-Romero P, Englert C, Sgroi DC, Smith BL, Younger JW, Garber JE, Duda RB, Mayzel KA, Isselbacher KJ, Friend SH, Haber DA (1996) Germ-line BRCA1 mutations in Jewish and
non-Jewish women with early-onset breast cancer. $N$ Engl J Med 334: $143-149$

Ford D, Easton DF, Stratton M, Narod S, Goldgar D, Devilee P, Bishop DT, Weber B, Lenoir G, Chang-Claude J, Sobol H, Teare MD, Struewing J, Arason A, Scherneck S, Peto J, Rebbeck TR, Tonin P, Neuhausen S, Barkardottir R, Eyfjord J, Lynch H, Ponder BA, Gayther SA, ZeladaHedman M and the Breast Cancer Linkage Consortium (1998) Genetic heterogeneity and penetrance analysis of the BRCA1 and BRCA2 genes in breast cancer families. Am J Hum Genet 62: 676-689

Frank TS, Deffenbaugh AM, Reid JE, Hulick M, Ward BE, Lingenfelter B, Gumpper KL, Scholl T, Tavtigian SV, Pruss DR, Critchfield GC (2002) Clinical characteristics of individuals with germline mutations in BRCA1 and BRCA2: analysis of 10,000 individuals. J Clin Oncol 20(6): $1480-1490$

Gayther SA, Pharoah PDP, Ponder BAJ (1998) The genetics of inherited breast cancer. J Mamm Gland Biol Neopasia 3: 365-376

Han W, Kang SY, The Korean Breast Cancer Society (2010) Relationship between age at diagnosis and outcome of premenopausal breast cancer: age less than 35 years is a reasonable cut-off for defining young age-onset breast cancer. Breast Cancer Res Treat 119(1): 193-200

Jmor S, Al-Sayer H, Heys SD, Payne S, Miller I, Ah-See A, Hutcheon A, Eremin $O$ (2002) Breast cancer in women aged 35 and under: prognosis and survival. $J$ R Coll Surg Edinb 47(5): 693-699

Krainer M, Silva-Arrieta S, Fitzgerald MG, Shiminda A, Ishoka C, Kanamuru R, Macdonald DJ, Unsal H, Finklestein DM, Bowcock A, Isselbacher KJ, Haber DA (1997) Differential contributions of BRCA1 and BRCA2 to early onset breast cancer. $N$ Engl J Med 336: $1416-1421$

Lakhani SR, Reis-Filho JS, Fulford L, Penault-Llorca F, van der Vijver M, Parry S, Bishop T, Benitez J, Rivas C, Bignon YJ, Chang-Claude J, Hamann U, Cornelisse CJ, Devilee P, Beckmann MW, Nestle-Kramling C, Daly PA, Haites N, Varley J, Lalloo F, Evans G, Maugard C, MeijersHeijboer H, Klijn JG, Olah E, Gusterson BA, Pilotti S, Radice P, Scherneck S, Sobol H, Jacquemier J, Wagner T, Peto J, Stratton MR, McGuffog L, Easton DF, Breast Cancer Linkage Consortium (2005) Breast Cancer Linkage Consortium. Prediction of BRCA1 status in patients with breast cancer using estrogen receptor and basal phenotype. Clin Cancer Res 11(14): $5175-5180$

Lalloo F, Varley J, Ellis D, Moran A, O'Dair L, Pharoah P, Evans DG (2003) Prediction of pathogenic mutations in patients with early-onset breast cancer by family history. Lancet 361: $1101-1102$

Lalloo F, Varley J, Moran A, Ellis D, O’Dair L, Pharoah P, Antoniou A, Hartley R, Shenton A, Seal S, Bulman B, Howell A, Evans DG (2006) 
BRCA1, BRCA2 and TP53 mutations in very early-onset breast cancer with associated risks to relatives. Eur J Cancer 42(8): 1143-1150

Li FP, Fraumeni JF, Mulvihill JJ, Blattner WA, Dreyfus MG, Tucker MA, Miller RW (1988) A cancer family syndrome in twenty-four kindreds. Cancer Res 48: 5358-5362

Loman N, Johannsson O, Kristoffersson U, Olsson H, Borg A (2001) Family history of breast and ovarian cancers and BRCA1 and BRCA2 mutations in a population-based series of early onset breast cancer. J Natl Cancer Inst 93: $1215-1223$

Nixon AJ, Neuberg D, Hayes DF, Gelman R, Connolly JL, Schnitt S, Abner A, Recht A, Vicini F, Harris JR (1994) Relationship of patient age to pathologic features of the tumor and prognosis for patients with stage I or II breast cancer. J Clin Oncol 12(5): 888-894

Parmigiani G, Berry DA, Aquilar O (1998) Determining carrier probabilities for breast cancer susceptibility genes BRCA1 and BRCA2. Am J Hum Genet 62: $145-148$
Peto J, Collins N, Barfoot R, Seal S, Warren W, Rahman N, Easton DF, Evans C, Deacon J, Stratton MR (1999) Prevalence of BRCA1 and BRCA2 gene mutations in patients with early onset breast cancer. J Natl Cancer Inst 91: $943-949$

Sidransky D, Tokino T, Helzlsouer K, Zehnbauer B, Rausch G, Shelton B, Prestigiacomo L, Vogelstein B, Davidson N (1992) Inherited p53 gene mutations in breast cancer. Cancer Res 52: $2984-2986$

Varley J, McGown G, Thorncroft M, Santibanez-Koref MF, Kelsey AM, Tricker KJ, Evans DGR, Birch JM (1997) Germ-line mutations of TP53 in Li-Fraumeni families: an extended study of 39 families. Cancer Res 14: $865-871$

Young SR, Pilarski RT, Donenberg T, Shapiro C, Hammond LS, Miller J, Brooks KA, Cohen S, Tenenholz B, Desai D, Zandvakili I, Royer R, Li S, Narod SA (2009) The prevalence of BRCA1 mutations among young women with triple-negative breast cancer. BMC Cancer 9: 86 